\title{
InfoNorth
}

\section{Tracking Long-Term Environmental Changes in Arctic Lakes and Ponds: A Paleolimnological Perspective}

\author{
by John P. Smol'
}

$\mathrm{H}$ IGH-LATITUDE REGIONS have repeatedly been identified as important reference areas for environmental change research, as they are especially sensitive to even small climatic changes and are often the first to show signs of environmental shifts. Moreover, climatic changes occurring at high latitudes have profound effects on other regions. Unfortunately, long-term monitoring data are generally lacking for most regions, and this is especially true for the Arctic. Without these data, it is difficult to determine whether environmental conditions are changing, and if so, to specify the magnitude and direction of change.

Fortunately, a variety of natural archives of environmental change (e.g., ice cores) can be used to reconstruct these missing data sets. One rapidly emerging area of research in the Arctic is paleolimnology, which is the science of reconstructing past lake and pond histories from the proxy data contained in sediment profiles (Smol, 2002). As lakes represent a common feature of most Arctic regions, paleolimnological techniques have now been applied to a wide variety of research questions (Pienitz et al., 2004). Dated sediment cores typically archive a very rich history of past limnological conditions, based on indicators such as fossil algae (especially diatoms and chrysophytes) and invertebrates (such as Cladocera and aquatic insect remains), as well as a suite of physical and chemical indicators, such as metals and contaminants (Smol, 2002).

My Arctic limnology and paleolimnology research program began in 1983, when Dr. Weston Blake Jr., now an emeritus scientist at the Geological Survey of Canada, invited me to join his field crew at Cape Herschel on eastern Ellesmere Island. I published an early paper (part of my $\mathrm{PhD}$ dissertation) arguing that fluctuating lake-ice conditions (which are closely related to climatic variables) exerted a strong control on lake biota, and hence on the bioindicators preserved in lake sediments. The 1983 field season was the start of a lifelong interest in the limnology

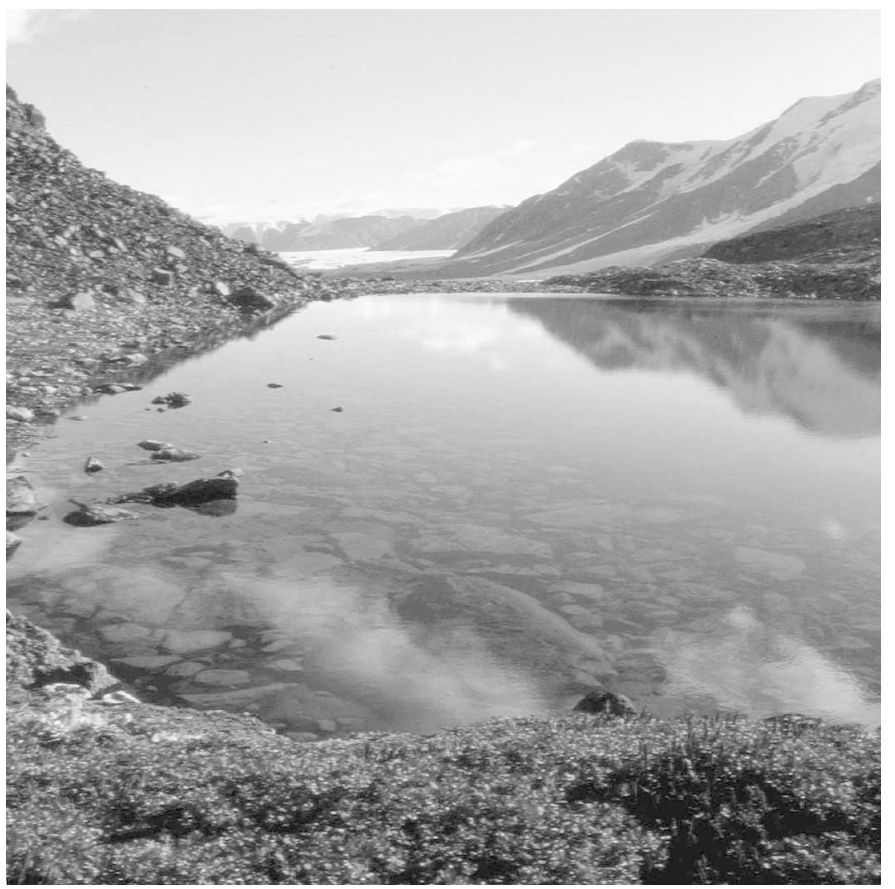

Rock Basin Lake, Baird Inlet (east-central Ellesmere Island, Nunavut, Canadian High Arctic) was the site of the first detailed paleolimnological study from the circumpolar region, which used diatom and chrysophyte microfossils to track past climatic change. Photo: John P. Smol, August 1987.

and paleoecology of Arctic lakes. In September 1984, I was hired as an assistant professor at Queen's University, where Marianne Douglas, now a professor in the Department of Geology at the University of Toronto and holder of a Tier 1 Canada Research Chair in Global Change, was among my first cohort of students. We have been collaborating on polar research ever since.

For over 20 years, we have been using both limnological and paleolimnological techniques to track a variety of environmental trends throughout the Arctic. I co-direct the

\footnotetext{
${ }^{1}$ Editor's Note: Following the announcement of Dr. Smol's award of the Gerhard Herzberg Canada Gold Medal for Science and Engineering, we invited him to profile his research in InfoNorth. Dr. Smol is a life member and fellow of the Arctic Institute of North America. The Herzberg Medal, Canada's top science prize, is awarded by the Natural Sciences and Engineering Research Council of Canada.
} 


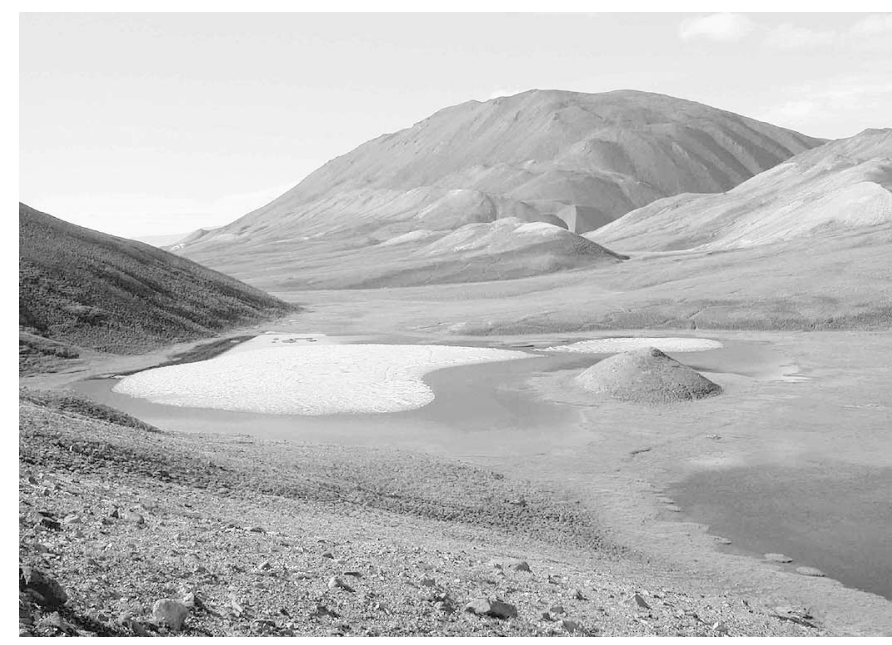

A typical lake from north-central Ellesmere Island, Nunavut, Canadian High Arctic. The central float of ice may persist throughout the summer during cool years in some lakes.

Photo: Bronwyn Keatley, July 2003.

Paleoecological Environmental Assessment and Research Lab (PEARL) at Queen's University, and Marianne heads the Paleoecological Assessment Lab (PAL) at the University of Toronto. Our combined research addresses some of the major environmental issues facing the Canadian Arctic and its peoples. Paleolimnological techniques allow us to test hypotheses on ecosystem succession and lake ontogeny that cannot be addressed using shorter-term approaches.

In 1983, very little was known about High Arctic limnology. As long-term environmental trends in lakes cannot be divorced from an understanding of present-day limnology, about half the resources of the PEARL and PAL research programs are dedicated to the study of present-day limnological conditions and processes in the Arctic. Over the last 23 years, we have surveyed over 1000 Arctic lakes and ponds, describing their present-day water chemistry and other limnological characteristics, as well as their biota (focusing mainly on diatom algae, our primary indicators of environmental change).

Although considerable effort is extended to the limnological surveys, the main research goals focus on long-term environmental change, as revealed through paleolimnological techniques. Diatoms (e.g., Douglas and Smol, 1999) and other indicators (Douglas et al., 2004a) preserved in lake sediments provide powerful biomarkers to assist in reconstructing long-term environmental trends. Some of the main questions posed by PAL and PEARL researchers have sought to determine 1) the extent, timing and magnitude of climatic change in the Arctic, and how recent changes differ from natural variability; 2) the influence of local human activities on freshwater resources; 3) the effects of multiple stressors (e.g., climate change, contaminants) on Arctic lake systems; and 4) the past population trajectories of important animal groups, such as sockeye salmon and seabirds, which can also significantly influence Arctic freshwater lakes. Collectively,

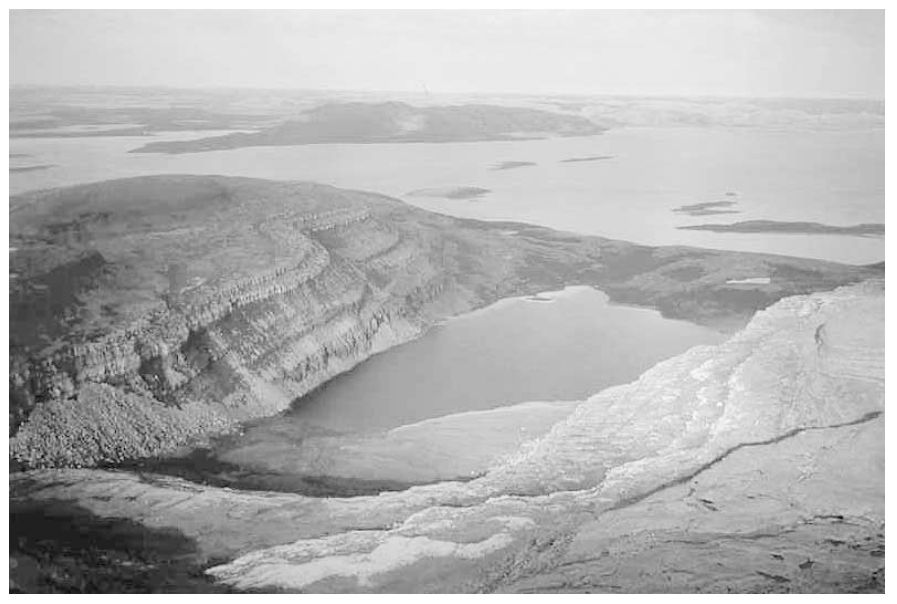

A subarctic lake from northern Québec (Nunavik). Photo: Reinhard Pienitz, August 2002.

these studies can broaden our understanding of Arctic ecosystems by providing long-term perspectives and highlighting the dynamic interactions with both natural and anthropogenic population drivers, as well as improve our awareness of resource distribution and abundance in relation to the traditional territories of Aboriginal peoples.

A major research effort focuses on tracking the natural and recent modes of climate change in Arctic lakes and ponds. Some of the most marked changes in aquatic sediment records were recorded in the first paleolimnological studies from Cape Herschel (Ellesmere Island), where we showed striking changes in fossil diatom assemblages (Douglas et al., 1994). After centuries of relatively stable conditions, the algal assemblage changed dramatically in the 1800 s, with a marked increase in species diversity, as well as a shift to taxa that suggested less extensive ice conditions. We interpreted these changes as being related to recent warming. Although this 1994 paper elicited considerable discussion and controversy in the scientific community, subsequent studies in many other Arctic regions have confirmed these interpretations. A recent paper summarizing 55 paleolimnological profiles from four polar countries described these ecological changes on a circumpolar basis (Smol et al., 2005). Interestingly, among its 26 co-authors were some of the researchers most skeptical of the original Douglas et al. paper. Another graduate of the PEARL lab, Professor Reinhard Pienitz of Laval University, has been conducting paleolimnological work primarily in northern Quebec and Labrador, which are important control areas for these climate-based studies.

Although environmental trends associated with climatic changes continue to be a major research focus, our programs also address a variety of other limnological and paleoenvironmental problems. For example, we have investigated how Arctic lakes have responded to direct human impacts, such as the effects of sewage input from local communities (e.g., Douglas and Smol, 2000). Working collaboratively with archeologists, we are also investigating the limnological repercussions of Thule Inuit 
whaling activities that took place centuries ago (e.g., Douglas et al., 2004b). Paleolimnological work on tracking past sockeye salmon populations in Alaska (e.g., Finney et al., 2000, 2002) and other Arctic regions, such as the Yukon, are also underway.

Since the mid-1980s, we have worked on all the major Canadian Arctic islands, as well as many smaller ones. Considerable work has also been completed in the Canadian Subarctic. Although this summary focuses mainly on Canadian lakes, our polar research has extended throughout the circumpolar region, with projects in Alaska, Greenland, Iceland, Lapland, Svalbard, and Siberia. Marianne also runs a research program in Antarctica.

Given the scarcity of monitoring data for the Arctic, it seems inevitable that paleoenvironmental approaches will be used increasingly in the future in lieu of the missing instrumental data that were never gathered for this vast and diverse region. Certainly much work remains. However, with the steady stream of advances that paleolimnology continues to enjoy, we can expect lake-sediment studies to provide many new insights concerning long-term environmental change.

\section{ACKNOWLEDGEMENTS}

Our Arctic research programs are funded primarily by the Natural Sciences and Engineering Research Council of Canada (NSERC), the Polar Continental Shelf Project, and the Northern Scientific Training Program. I thank Karen McCullough for asking me to provide this short summary of our Arctic programs following the award of the 2004 NSERC Herzberg Gold medal for science and engineering.

\section{REFERENCES}

DOUGLAS, M.S.V., and SMOL, J.P. 1999. Freshwater diatoms as indicators of environmental change in the High Arctic. In: Stoermer, E.F., and Smol, J.P., eds. The diatoms: Applications for the environmental and earth sciences. Cambridge: Cambridge University Press. 227-244. 2000. Eutrophication and recovery in the High Arctic: Meretta Lake revisited. Hydrobiologia 431:193-204.
DOUGLAS, M.S.V., SMOL, J.P., and BLAKE, W., Jr. 1994. Marked post-18th century environmental change in High Arctic ecosystems. Science 266:416-419.

DOUGLAS, M.S.V., SMOL, J.P., SAVELLE, J.M., and BLAIS, J.M. 2004a. Prehistoric Inuit whalers affected Arctic freshwater ecosystems. Proceedings of the National Academy of Sciences 101:1613-1617.

DOUGLAS, M.S.V., SMOL, J.P., PIENITZ, R., and HAMILTON, P. 2004b. Algal indicators of environmental change in Arctic and Antarctic lakes and ponds. In: Pienitz, R., Douglas, M.S.V., and Smol, J.P., eds. Long-term environmental change in Arctic and Antarctic lakes. Dordrecht: Springer. 117-157.

FINNEY, B., GREGORY-EAVES, I., SWEETMAN, J., DOUGLAS, M., and SMOL, J.P. 2000. Impacts of climatic change and fishing on Pacific salmon abundance over the past 300 years. Science 290:795-799.

FINNEY, B.P., GREGORY-EAVES, I., DOUGLAS, M.S.V., and SMOL, J.P. 2002. Fisheries productivity in the northeastern Pacific Ocean over the past 2,200 years. Nature 416:729-733.

PIENITZ, R., DOUGLAS, M.S.V., and SMOL, J.P., eds. 2004. Long-term environmental change in Arctic and Antarctic lakes. Dordrecht: Springer. 562 p.

SMOL, J.P. 2002. Pollution of lakes and rivers: A paleoenvironmental perspective. London: Hodder Publishers and New York: Oxford University Press. 280 p.

SMOL, J.P., WOLFE, A.P., BIRKS, H.J.B., DOUGLAS, M.S.V., JONES, V.J., KORHOLA, A., PIENITZ, R., RÜHLAND, K., SORVARI, S., ANTONIADES, D., BROOKS, S.J., FALLU, M.-A., HUGHES, M., KEATLEY, B.E., LAING, T.E., MICHELUTTI, N., NAZAROVA, L., NYMAN, M., PATERSON, A.P., PERREN, B., QUINLAN, R., RAUTIO, M., SAULNIER-TALBOT, É., SIITONEN, S., SOLOVIEVA, N., and WECKSTRÖM, J. 2005. Climate-driven regime shifts in the biological communities of Arctic lakes. Proceedings of the National Academy of Sciences 102:4397-4402.

John P. Smol is a professor in the Department of Biology at Queen's University and holder of the Canada Research Chair in Environmental Change. He is co-director of the Paleoecological Environmental Assessment and Research Lab (PEARL). Additional publications and information are available at the PEARL website: http://biology.queensu.ca/ $\sim$ pearl/. 